\title{
Voorbij het ongemak over religie
}

\author{
Sociaalliberalisme en religie
}

Joost Röselaers

Dit is het tweede artikel in de reeks waarin de religieuze grondslag van een politieke partij wordt toegelicht. ${ }^{1}$ In dit artikel wordt de D66-zienswijze op religie toegelicht.

\section{Inleiding}

'Onze tijdgenoten, of zij nu geloven of niet geloven, hebben het nodig ook een ander perspectief op de mens te horen dan alleen het materiële. Er moet een andere dorst worden gelest: de dorst naar het absolute. Het gaat niet om bekering, maar om een geluid vanuit religie, samen met anderen, dat nog steeds over de mens durft te spreken als een levende geest.'

Dat de tijden veranderen blijkt uit de voorgaande uitspraken van Emmanuel Macron, de Franse president, die min of meer als een voorman beschouwd wordt van het sociaalliberalisme in Europa. Zo riep hij op 9 april 2018 tijdens een ontmoeting met katholieke bisschoppen op tot herwaardering van religie. ${ }^{2}$ Dat lijkt verrassend in een land dat staat voor de laïcité, de strikte scheiding van kerk en staat.

De tijden zijn ook in Nederland aan het veranderen. De ontzuiling is in grote delen van ons land voltooid en dat vraagt om andere opvattingen over religie. Het is als betrokken D66'er én als actief remonstrants predikant mijn stellige overtuiging dat D66 zichzelf en ook de samenleving tekortdoet door expliciet of schijnbaar religieuze verbanden uit te willen sluiten van haar gedachtegoed.

Sinds 2017 ben ik hoofdredacteur van Idee, het politiek-wetenschappelijke tijdschrift van de Mr. Hans van Mierlostichting (het wetenschappelijk instituut dat gelieerd is aan D66). Het tijdschrift heeft als doelstelling om het sociaalliberalisme te verdiepen en verbreden. Dat is de politieke stroming waar D66 zich op baseert en die nog volop in ontwikkeling is. Het eerste nummer van Idee onder mijn hoofdredacteurschap ging over religie. Dat was volstrekt toevallig (ik laat in het midden of het gepredestineerd was). De redactie bepaalt immers maanden

1 Het eerste artikel over de Vlaamse christendemocratie verscheen in Tijdschrift voor Religie, Recht en Beleid 2018, 2 (W. Beke, 'De C van CD\&V Christelijke waarden bij de Vlaamse christendemocraten'.

2 De toespraak is na te lezen op www.elysee.fr/emmanuel-macron/2018/04/09/discours-dupresident-de-la-republique-emmanuel-macron-a-la-conference-des-eveques-de-france-au-collegedes-bernardins. 
van tevoren de thema's. Ik had het als predikant zelf overigens niet durven voor te stellen. De keuze van de redactie is verrassend te noemen. Gewaagd, misschien wel. De eerste reactie van veel sociaalliberalen bij het onderwerp religie is immers iets in de trant van: 'Oh my God!' En dat is dan ook de titel geworden van die editie van Idee. En de ondertitel luidde: 'Het ongemak over religie'. ${ }^{3}$

In dat nummer van Idee reflecteerden verschillende schrijvers (al dan niet verbonden aan D66) op een sociaalliberale visie op religie. Ik liet nadrukkelijk anderen aan het woord. De uitnodiging van het Tijdschrift voor Religie, Recht en Beleid om te schrijven over 'een filosofische, politieke en - voor zover relevant - theologische onderbouwing van de visie van religie in het politieke beleid van D66' neem ik daarom van harte aan. Het zijn met name persoonlijke observaties en gedachten; er zijn immers amper publicaties verschenen over dit vraagstuk. Ik ben zo vrij om er ook aanbevelingen aan toe te voegen voor toekomstig sociaalliberaal beleid en gedachtegoed rond religieuze vraagstukken. Het is de hoogste tijd om het ongemak op dit punt los te laten. Het is een ongemak waar ik mij sinds mijn lidmaatschap van de partij in 1998 over verwonder. Over veel onderwerpen is men ontvankelijk en openhartig, maar religie vormt daarop een uitzondering ('religie en het koninklijk huis, dat zijn de twee onderwerpen waar D66 zich volstrekt geen raad mee weet', vertrouwde een oude D66-prominent mij recentelijk toe). De tijden zijn aan het veranderen, de ontzuiling is in grote delen van het land voltooid, en dat vraagt om andere opvattingen over religie dan die wij gewoon zijn in de verzuilde christelijke samenleving van vandaag.

\section{Historische schets van sociaalliberalisme en religie}

D66 ontstond in het jaar 1966, in de nadagen van de verzuiling. Doel van de oprichters was onder andere om het verzuilde politieke bestel te laten 'ontploffen'. ${ }^{4}$ De geest van de Parijse studentenrevolte van mei 1968 zwierf al rond. De oprichters van de partij distantieerden zich nadrukkelijk van in hun ogen paternalistische en onderdrukkende religies. Een zeker antireligieuze houding maakte onderdeel uit van het DNA van de partij. Het is decennialang bon ton geweest om kritiek te leveren op religie. De invloed van kerken moest zo veel mogelijk beperkt worden, en verwijzingen naar religie en het christendom in het bijzonder lagen haast in de taboesfeer. ${ }^{5}$

Vanuit D66 is in die jaren weinig nagedacht over de relatie tot religie, en zeker niet in opbouwende zin. Als een visie op dit onderwerp te ontdekken viel in sociaalliberale kring, dan was dat naar het model van de Franse laïcité. Volgens de laïcité is de staat strikt neutraal. Niemand - geen individu en geen organisatie heeft het recht om zijn of haar levensovertuiging in de publieke ruimte aan anderen op te leggen. Voor zover D66'ers een mening hadden over religie in het politieke domein, dan hanteerden velen van hen de opvatting dat de publieke

3 'Oh my God, over de terugkeer van religie', Idee 2018, 202.

4 M. van der Land, Langs de afgrond, Eburon 2012, p. 13.

5 C. Brummer \& D. Boomsma, De canon van het sociaal-liberalisme, Boom 2019, p. 181. 
ruimte ontdaan diende te worden van referenties aan het christendom. Een aantal D66'ers riep nadrukkelijk op om op te komen voor een niet-religieuze levenshouding. In zijn bijdrage in Idee over religie verwoordt prof. dr. Herman Philipse deze houding als volgt:

'Mijn inziens zouden politici, die door goed na te denken, tot de conclusie zijn gekomen dat er geen enkele god bestaat, hun atheïsme openlijk kenbaar moeten maken. Niet alleen geven ze dan fatsoenlijk intellectueel tegenwicht aan vertegenwoordigers van bijvoorbeeld de Christenunie die hun godsgeloof publiekelijk belijden. Ook zullen ze door een dergelijke openhartigheid laten zien dat ze een intellectueel geweten hebben en worden gemotiveerd door waarheidsliefde. ${ }^{6}$

Herman Philipse verwoordt hier gedachten die breed leven in de partij. Meedoen aan een coalitie met de ChristenUnie was om die reden voor veel D66-leden in 2017 volstrekt not-done (ironisch genoeg hoor ik ondertussen van direct betrokkenen dat de ChristenUnie als de meest betrouwbare en constructieve coalitiepartij wordt beschouwd).

Dit alles heeft ertoe bijgedragen dat D66 al decennialang het imago heeft dat zij niet of soms zelfs antichristelijk is. Daar zit iets clichématigs in, maar ik ontdek er ook een kern van waarheid in. Het sluit aan bij mijn persoonlijke ervaring met (oudere) partijleden. Als in de aanwezigheid van oudere partijleden religie ter sprake komt, dan is hun reactie 'Oh my God' - en dat bedoelen zij dan negatief. Het geloof is immers toch passé. We hebben ondertussen wel afscheid genomen van een beklemmende kerk.

En laten we wel wezen: dat is nog steeds het dominante beeld onder D66'ers en vele andere partijen. Religie is een bron van spot en kritiek. Vijf jaren geleden was dominee Gremdaat (een karikatuur gespeeld door Paul Haenen) te gast bij een D66-congres en werd hij door de dagvoorzitter verwelkomd met de woorden: 'U bent de enige predikant die ik ooit als spreker op een D66-congres zal toelaten.' En de hele zaal lachte. Niemand die er na afloop iets over zei. Ik kan er zelf ook wel de humor van inzien, maar vraag mij tegelijk af of een dergelijke opmerking ook gemaakt zou kunnen worden over een andere beroepsgroep, en zeker over geestelijke leiders van andere religieuze tradities ('u bent de enige imam die ik ooit op een congres zal toelaten'). Bij het verschijnen van het nummer van Idee over religie namen twee oud-Kamerleden van D66 (nu tachtigers) contact met mij op. Zij waren opgelucht dat religie eindelijk ter sprake kwam binnen de partij. In hun tijd was dat naar eigen zeggen ondenkbaar geweest. Een van de twee sprak in dit kader van een 'coming out' als gelovige binnen de partij, iets wat ze als volksvertegenwoordiger niet had aangedurfd.

Een aantal D66'ers waarschuwde overigens voor de effecten hiervan. In zijn bijdrage aan de algemene beschouwingen in 1976 zei fractievoorzitter Jan Terlouw: 
'De kerken kunnen de mensen niet meer klein houden, waaraan zij zich vroeger nogal eens schuldig maakten; maar zij die God dood verklaarden, hebben verzuimd de ontredderde gelovigen een andere "zin van het leven" voor te houden. Terwijl de materiële voorzieningen toenamen, is er in het veld van de niet-materiële waarden veel gekapt en weinig geplant.' ${ }^{7}$

\section{Sociaalliberalisme en religie nu}

Hoe wordt er anno 2019 naar religie gekeken vanuit sociaalliberale kringen? Ik spreek ook hier met name uit eigen ervaring, want literatuur en onderzoek ontbreken hierover, ook al bestaat er een licht kwijnende landelijke D66-werkgroep Levensbeschouwing en Religie. Ik observeer een kentering. Als de generaties na mij (ik ben van 1979) zeggen 'Oh my God, een gelovige' en zeker 'Oh my God, een dominee!', dan zit daar iets in van nieuwsgierigheid. Zij willen er meer van weten. Laat ons toch weten wat $\mathrm{u}$ dan gelooft! Ik merk het aan de uitnodigingen die ik ontvang binnen de partij om te spreken. Men staat er nu veel meer open en onbevangen in. Neem bijvoorbeeld het initiatief van de jonge redactieleden van Idee om een nummer te wijden aan religie.

Er valt onder deze generatie echter ook een ongemak te ontdekken, dat niet zozeer afwijzend is, zoals voorheen, maar samenvalt met een 'niet weten'. In mijn jaren als predikant in Londen kwam in 2016 eens een grote groep jonge D66'ers langs tijdens een van mijn kerkdiensten. Het was een bevreemdende ervaring voor alle partijen. Zij hadden zelden een kerkdienst meegemaakt en wisten zich moeilijk een houding te geven. Daar valt van alles over te zeggen, maar kenmerkend was dat zij het initiatief hadden genomen om eens een kerkdienst te bezoeken. Die nieuwsgierigheid verraste mij. $\mathrm{Na}$ afloop hadden we een levendig gesprek over wat ik versta onder religie, en wat de betekenis van religie zou kunnen zijn in de samenleving. Dat gesprek verliep in alle openheid en nieuwsgierigheid.

Een kentering ontdek ik ook onder de huidige bestuurders. In een interview met het Nederlands Dagblad op 18 mei 2019 bevestigde fractievoorzitter Rob Jetten mijn waarnemingen en voegde er een aansporing aan toe:

'D66 is opgericht in een tijd waarin de verzuiling nog sterk was, en veel individuele vrijheden die we nu hebben, niet of maar beperkt bestonden. Dat bepaalt wel het sentiment onder de oudere generatie D66'ers. Ik denk dat dit onder de nieuwe generatie veel minder speelt. Daarom hoop ik dat we ook het gesprek over geloof op een nieuwe manier kunnen voeren. Ik zie binnen onze partij heftige discussies over de vrijheid van onderwijs, ritueel slachten, en jongensbesnijdenis. Het is echt niet zo dat iedereen binnen D66 zegt: inperken die onderwijsvrijheid, of stoppen met ritueel slachten.' 


\section{Verhouding van sociaalliberalen tot religie, met name het christendom: een aantal concrete voorstellen}

Het ongemak over religie uit zich onder de huidige generatie D66'ers vanwege hun 'niet weten', en veel minder vanwege een antihouding. In Idee vond ik het daarom nodig om in de inleiding te vertellen waar religie volgens mij voor staat. Religie draait wat mij betreft om drie dingen: verbindingen leggen (de oorspronkelijke betekenis van 'religere' is 'verbinden'), waarden versterken, en een besef van het transcendente (iets wat ons eigen leven overstijgt). Alle drie dingen doet religie door middel van verhalen en rituelen. Voor sociaalliberalen ligt hier een kans tot verrijking (trouwens, voor de gehele samenleving). Maar daarvoor moet men wel over het ongemak heen willen stappen. Te beginnen met de verhouding tot het christendom. Vanaf haar oprichting leefde D66 in zekere zin in een antithetische verhouding tot christelijke partijen, en daarmee ook tot het christelijk geloof dat aan deze partijen ten grondslag lag. Daarmee doet de partij de samenleving tekort, alleen al vanwege de geschiedenis. Al eeuwenlang is het christendom zeer nauw verweven met de Nederlandse samenleving. Onze cultuur en de ontwikkeling van onze waarden zijn onlosmakelijk verbonden met het christendom. De keerzijde daarvan is genoegzaam bekend, maar daarmee moeten we niet het kind met het badwater wegspoelen.

Hoe kan een verhouding van sociaalliberalen tot het christendom er wel uitzien, waarin het als een verrijking beschouwd wordt? Dat is overigens een vraag die elke politieke partij, ja, de samenleving als geheel, zich kan stellen. De secularisering heeft zich in Nederland rap voltrokken en dat heeft invloed op de wijze waarop wij ons verhouden tot de dominante religie van weleer. Deze vraag geldt echter met name voor het sociaalliberalisme, dat niet vastzit aan een bepaalde ideologie en dat, zoals eerder opgemerkt, nog niet uitgebreid heeft nagedacht over zijn verhouding tot religie en met name het christendom. Ik denk zelf aan de volgende drie concrete punten.

Ten eerste: religieuze feestdagen laden met betekenis. Onze kalender ademt nog steeds op de christelijke feestdagen. Deze feestdagen hebben voor velen echter geen diepgaande betekenis meer. Feestdagen bieden voor politici een kans om te spreken over hun diepste drijfveren en idealen. Ik heb dat zelf ervaren in het Verenigd Koninkrijk. Met Kerstmis en Pasen vertellen de leiders van de grote partijen hoe zij het feest ervaren, en laden het daarmee met (seculiere) betekenis. Er zijn meer dan genoeg aanknopingspunten: het thema van licht en donker, perspectief in een uitzichtloze situatie, de hoop op een ommekeer.

Ten tweede: aandacht voor de gebouwen. Kerken behoren niet alleen gelovigen toe! Ook dit is een punt dat ik meeneem uit het Verenigd Koninkrijk. Kerken behoren plekken van zingeving en ontmoeting te zijn voor allen. Kerken ademen een bepaalde troostrijke sfeer. Het verbaasde mij vanuit Londen dat de nationale herdenking in Nederland van de MH17-ramp plaatsvond in de RAI. Een van de meest troosteloze plekken die ik ken! Claim daarvoor de Nieuwe Kerk, ook op 4 mei een nationale plek van herdenken. Bemoedigend is in dat kader het besluit 
van het kabinet om 325 miljoen euro uit te trekken voor het behoud van erfgoed en monumenten, met name kerkgebouwen. Cultuurminister Ingrid van Engelshoven van D66 zei daarover in NRC van 8 augustus 2019, naar aanleiding van een dreigende kerksluiting bij haar in de buurt:

'Want of een kerk nou katholiek is of protestant, of mensen gelovig zijn of niet - als er iets met de kerk dreigt te gebeuren krijgen ze opeens iets van: dit is onze kerk, hij staat in onze buurt, hier willen wij over meebeslissen. Een kerk is de herkenbaarheid van je buurt, je dorp, je stad. Het is ook de plek waar iedereen welkom is.' ${ }^{9}$

Ten derde: het belang van het vertellen van verhalen, ook de Bijbelse. In 2006 heeft D66 haar uitgangspunten vastgelegd in vijf richtingwijzers. Het zijn doordachte teksten, waar geen speld tussen te krijgen is. Maar het is nog geen 'levende getuigenis', het beklijft maar moeizaam. Het christendom (en andere religies) brengt zijn gedachtegoed ter sprake door het vertellen van verhalen. Een verhaal betrekt je erbij, het beklijft, en je internaliseert het. In onze gesprekken over waarden en identiteit zouden we het belang van het vertellen van verhalen niet uit het oog moeten verliezen. En ook niet het feit dat christelijke verhalen dragers van onze waarden kunnen zijn. Ik noem het verhaal van de barmhartige samaritaan. Van de overspelige vrouw. Al eeuwenlang laten mensen zich erdoor raken en vormen. Deze traditie mag niet binnen een generatie verloren gaan.

En ten slotte nog een algemene aansporing voor sociaalliberalen: niet te leven naar de letter van de wet, maar naar de geest ervan. De oproep tot de zondagsrust gaat niet alleen over de doodse stilte op de zondag en het verbod op elke vorm van arbeid op die dag. Het gaat erom dat een individu en een samenleving ook tot rust moeten komen, zodat zij weer opnieuw op adem komen. Of, ander recent vraagstuk, het voorstel van D66 om 'bij gratie Gods' te schrappen uit de afkondiging van wetsvoorstellen die de koning ondertekent. 'Een principekwestie', aldus de partij. Maar dan? Als je het afschaft, dan tekent de koning de wetten louter namens hemzelf. En dat wil je juist niet. Met 'de gratie Gods' geeft de koning aan dat hij niet alleen aan zichzelf verantwoording schuldig is. En dat hij werkt binnen een breder kader - en dat hij zelf ook niet almachtig is. Hoe geef je daar woorden aan als je deze leus afschaft? Welke geest zit er kortom achter de letter? Ik wijs wat dit betreft graag op een toespraak van Jan Terlouw uit 1979, waarin hij stelt: 'Belangrijker is het besef dat er nieuwe normen nodig zijn die stoelen op oude waarden, zoals menselijke waardigheid en wederzijds respect. ${ }^{\prime 10}$

\section{Verhouding van sociaalliberalen tot de islam}

De verhouding van sociaalliberalen tot de islam is ook omgeven door ongemak, maar om andere redenen dan bij het christendom. In het algemeen was het beeld 
vanaf de jaren zestig binnen de partij, maar ook breder in de samenleving, dat religie op haar retour was. Daar heeft men van terug moeten komen. In de eerste plaats blijkt religie wereldwijd geheel niet op haar retour te zijn, maar nog steeds een wezenlijke rol te spelen in de levens van miljarden individuen. In de tweede plaats heeft men in Nederland de afgelopen decennia kennisgemaakt met een nieuwe religie, de islam. Het is nieuw en onbekend. Wij weten er ons geen raad mee. Mogen we bijvoorbeeld grappen maken over hun praktijken, zoals we dat ook doen bij christelijke praktijken? Bij D66 - de partij die voorop heeft gelopen in de kritiek op christelijke praktijken - is het dilemma het meest zichtbaar. Er is (terecht) forse verontwaardiging over een predikant die antihomo-uitspraken doet. Bij een imam die dergelijke uitspraken doet, is het daarentegen akelig rustig vanuit D66-hoek. Een van de grote dilemma's voor D66'ers op het vlak van religie is het boerkaverbod. Aan de ene kant staat (godsdienst)vrijheid voorop, als onopzegbare waarde. Aan de andere kant gaat de boerka in tegen vele verworvenheden waar de partij decennialang voor gestreden heeft. D66-politici waren opvallend rustig op social media over dit onderwerp.

De Nederlandse strikte scheiding kerk-staat is een groot goed en dat geldt ook in de verhouding tot de islam. Bij die verhouding horen ook religiekritiek en een objectieve blik. In zekere zin geef je daarmee aan dat de islam er volledig bij hoort en geen status aparte verdient.

D66 is een product van de Nederlandse secularisatie. Maar de secularisatie die nu in islamitische hoek plaatsvindt, daar heeft D66 bijzonder weinig aandacht voor. Vanuit D66-hoek kwam recentelijk het voorstel om op te komen voor de rechten van ongelovigen in het buitenland. ${ }^{11}$ Dit roept vragen op. Het voorstel lijkt vooral gericht op afvallige moslims, wat door D66 echter niet benoemd wordt. Ten tweede werd in het voorstel niet gerept over ex-moslims in eigen land, die vaak ook problemen ervaren vanwege hun ongeloof. Er is dus wel aandacht voor deze problematiek over de grens, maar niet in eigen land.

De drie punten die ik hiervoor noemde waarin christendom een verrijking kan zijn voor het sociaalliberalisme, gelden ook voor de islam (het derde punt, de gebouwen, is vanwege de korte geschiedenis en traditie nog niet relevant - met een nadruk op 'nog'). Allereerst de verhalen. Ook de islam is gebouwd op verhalen die inzicht en perspectief bieden. Deze verhalen, die aan de basis staan van de islam, mogen breder worden gedeeld in de samenleving om de onderlinge samenhang te versterken. En dat geldt evenzo voor de feestdagen. In 2017 pleitte ik er in $N R C$ voor om van het Suikerfeest een nationale feestdag te maken. ${ }^{12}$ Ik twijfel er ondertussen aan of je nieuwe feestdagen wel aan een bepaalde religie moet verbinden in plaats van aan een waarde of aan een gebeurtenis die in het collectieve geheugen gegrift is. Ik pleit er wel voor om bijvoorbeeld het Suikerfeest te laden met betekenis die ook niet-moslims weet te raken. Ik denk ook hier aan Britse politici die niet alleen vertellen wat hen raakt aan christelijke feestdagen, maar

11 Initiatiefnota 'Vrij zijn om niet te geloven', zie https://d66.nl/content/uploads/sites/2/2019/08/ Initiatiefnota_Sjoerdsma_niet-gelovigen.pdf.

12 www.nrc.nl/nieuws/2017/05/31/ruil-tweede-pinksterdag-in-voor-suikerfeest-10802847a1561109. 
ook aan joodse, hindoeïstische en islamitische feesten. Hier ligt een kans om verbindingen te leggen en om samenhang te scheppen die verder gaat dan de religieuze grenzen.

\section{Slotgedachten}

\section{Voorbij het ongemak over religie}

Het ongemak bij sociaalliberalen is de laatste jaren van kleur aan het veranderen. Het is nu minder met een antigevoel verbonden, maar veel méér met een niet weten. Er ligt een taak bij religieuze instituties en leiders om te vertellen waar zij voor staan en om de verhalen uit hun traditie te delen. De tijd is voorbij dat religies konden schuilen binnen hun eigen zuilen. Daar doen religies immers zichzelf, maar zeker ook de samenleving als geheel, tekort mee. Wij kunnen als samenleving niet leven zonder verbindende verhalen, plekken die geladen zijn met betekenis, en feesten die ons eraan herinneren wie wij zijn en wat wij willen worden.

\section{Religie is een alledaags feit waar je mee moet leren samenleven}

Ik zou daarnaast ook willen waarschuwen voor religieblindheid. Als je als politici heden ten dage religie niet meer begrijpt, dan begrijp je ook een deel van de processen in de maatschappij niet. Als je niet snapt hoeveel religie voor mensen kan betekenen, kun je ook niet altijd hun handelen verklaren. Ik denk bijvoorbeeld aan radicalisering. Als je niet snapt dat mensen bereid zijn te sterven voor hun religieuze overtuiging en het verdedigen van medegelovigen dan ga je naar andere oorzaken hiervoor zoeken en kun je nog wel eens de plank misslaan in het maken van beleid op dit terrein. Dit geldt ook voor andere minder drastische vraagstukken in de huidige samenleving waarbinnen religie een rol speelt. In elke fractie zou je daarom eigenlijk ook religieuzen moeten hebben (diversiteit!) om ervoor te zorgen dat de kennis op dit gebied aanwezig is.

\section{Ook sociaalliberalen zijn cultuurchristenen}

De afgelopen tijd claimen politici aan de rechterflank van het politieke spectrum de term 'cultuurchristen'. Zij behoren niet tot een kerk, maar staan wel voor de christelijke traditie. Heel diepgaand is deze betrokkenheid dikwijls niet en vaak wordt zij gebruikt om aan te tonen dat de islam juist niet bij Nederland hoort. Het is jammer dat de term 'cultuurchristen' daarom zo'n negatieve klank heeft gekregen bij mensen uit het midden van het politieke spectrum. In zekere zin zijn velen van ons immers cultuurchristenen. Hoeveel D66'ers zijn niet geroerd door de Mattheus Passion van Bach, of door Bijbelse taferelen van Rembrandt? En vermoeden ook D66'ers niet dat de betekenis van Kerstmis verder reikt dan een zelfgenoegzame maaltijd aan een keurig gedekte tafel?

Daarnaast vindt naar mijn mening, vooral vanuit mijn visie en ervaring als remonstrants predikant, zowel het liberalisme als de Verlichting (waar sociaalliberalen zich verwant mee voelen) hun wortels in het christendom. De Canadese filosoof Charles Taylor heeft in A Secular Age (2007) geanalyseerd hoe christendom en moderniteit elkaar wederzijds beïnvloed hebben. Aan het moderne paradigma 
heeft de christelijke traditie veel inzichten te danken. Omgekeerd zijn veel 'moderne' inzichten ontstaan uit christelijk geïnspireerde bronnen. Volgens de Brits-Amerikaanse filosoof Larry Siedentop is onze seculiere liberale maatschappij, waarin het vrije individu het organiserend principe is, het buitenechtelijk kind van het christendom. ${ }^{13}$ De stromingen zijn als een spiegel voor elkaar. Waar de moderniteit bedreven is in religiekritiek, draagt de christelijke theologie bij door middel van moderniteitskritiek. Dat laatste is nodig, omdat ook de moderniteit bepaald niet alleen vredelievend en tolerant is.

Een sociaalliberale cultuurchristen moet wel weten waar hij aan begint. Hij bekent dan kleur en maakt deel uit van een traditie die bovenal kritisch is op de bestaande orde en op gewoontes en moraal. Het is een traditie die een tegenover is, een spiegel en vragen oproept bij de gang der dingen. Juist dat tegenover mag niet aan de vergetelheid ontrukt worden. Hoe onuitstaanbaar ook, het zal ons altijd wenken naar een toekomst die voor allen beter is dan de wereld waar wij ons momenteel in bevinden. Het is mijn ervaring dat sociaalliberalen juist om die reden betrokken geraakt zijn bij de politiek.

Ik pleit er daarom van harte voor om die betrokkenheid te laden met de betekenis van religieuze verhalen, zodat onze tijdgenoten een ander perspectief op de mens horen dan alleen het materiële. Het waren en zijn immers juist deze verhalen die voor christenen (en moslims en ook atheïsten) telkens weer aanleiding vormen om in de spiegel te kijken. Hoe intolerant waren we? Hoe intolerant ben ik vandaag? Deze spiegel is van blijvende waarde, voor christenen, moslims, atheïsten, voor cultuurchristenen in alle soorten en maten en voor de samenleving als geheel. 